\title{
Hot topics in biodiversity and climate change research
}

\section{[version 1; peer review: 2 approved]}

\author{
Barry W. Brook ${ }^{1}$, Damien A. Fordham²
}

${ }^{1}$ School of Biological Sciences, Private Bag 55, University of Tasmania, Hobart, 7001, Australia

${ }^{2}$ The Environment Institute and School of Earth and Environmental Sciences, University of Adelaide, Adelaide, SA, 5005, Australia

V1 First published: 30 Sep 2015, 4(F1000 Faculty Rev):928

https://doi.org/10.12688/f1000research.6508.1

Latest published: 30 Sep 2015, 4(F1000 Faculty Rev):928

https://doi.org/10.12688/f1000research.6508.1

\section{Abstract}

With scientific and societal interest in biodiversity impacts of climate change growing enormously over the last decade, we analysed directions and biases in the recent most highly cited data papers in this field of research (from 2012 to 2014). The majority of this work relied on leveraging large databases of already collected historical information (but not paleo- or genetic data), and coupled these to new methodologies for making forward projections of shifts in species' geographical ranges, with a focus on temperate and montane plants. A consistent finding was that the pace of climate-driven habitat change, along with increased frequency of extreme events, is outpacing the capacity of species or ecological communities to respond and adapt.

\section{Keywords}

biodiversity, climate change, global change, conservation

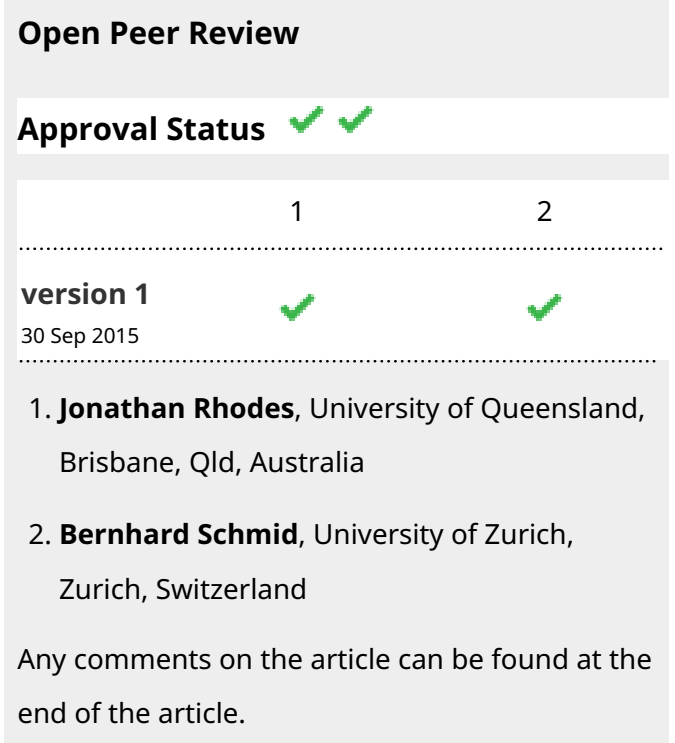

Corresponding author: Barry W. Brook (barry.brook@utas.edu.au)

Competing interests: The authors declare that they have no disclosures or conflicts of interest.

Grant information: This work was supported by Australian Research Council Discovery Grant DP120101019 (Brook) and Future Fellowship FT140101192 (Fordham).

Copyright: (c) 2015 Brook BW and Fordham DA. This is an open access article distributed under the terms of the Creative Commons Attribution License, which permits unrestricted use, distribution, and reproduction in any medium, provided the original work is properly cited.

How to cite this article: Brook BW and Fordham DA. Hot topics in biodiversity and climate change research [version 1; peer review: 2 approved] F1000Research 2015, 4(F1000 Faculty Rev):928 https://doi.org/10.12688/f1000research.6508.1

First published: 30 Sep 2015, 4(F1000 Faculty Rev):928 https://doi.org/10.12688/f1000research.6508.1 


\section{Introduction}

It is now halfway through the second decade of the $21^{\text {st }}$ century, and climate change impact has emerged as a "hot topic" in biodiversity research. In the early decades of the discipline of conservation biology (1970s and 1980s), effort was focused on studying and mitigating the four principal drivers of extinction risk since the turn of the $16^{\text {th }}$ century, colourfully framed by Diamond ${ }^{1}$ as the "evil quartet": habitat destruction, overhunting (or overexploitation of resources), introduced species, and chains of extinctions (including trophic cascades and co-extinctions). Recent work has also emphasised the importance of synergies among drivers of endangerment ${ }^{2}$. But the momentum to understand how other aspects of global change (such as a disrupted climate system and pollution) add to, and reinforce, these threats has built since the Intergovernmental Panel on Climate Change reports ${ }^{3}$ of 2001 and 2007 and the Millennium Ecosystem Assessment ${ }^{4}$ in 2005.

Scientific studies on the effects of climate change on biodiversity have proliferated in recent decades. A Web of Science (webofscience.com) query on the term "biodiversity AND (climate change)", covering the 14 complete years of the $21^{\text {st }}$ century, shows the peer-reviewed literature matching this search term has grown from just 87 papers in 2001 to 1,377 in 2014. Figure 1 illustrates that recent scientific interest in climate change-related aspects of biodiversity research has outpaced - in relative terms - the baseline trend of interest in other areas of biodiversity research (i.e., matching the query "biodiversity NOT (climate change)"), with climaterelated research rising from $5.5 \%$ of biodiversity papers in 2001 to $16.8 \%$ in 2014.
Interest in this field of research seems to have been driven by a number of concerns. First, there is an increasing societal and scientific consensus on the need to measure, predict (and, ultimately, mitigate) the impact of anthropogenic climate change ${ }^{5}$, linked to the rise of industrial fossil-fuel combustion and land-use change ${ }^{6}$. Biodiversity loss and ecosystem transformations, in particular, have been highlighted as possibly being amongst the most sensitive of Earth's systems to global change ${ }^{7,8}$. Second, there is increasing attention given to quantifying the reinforcing (or occasionally stabilising) feedbacks between climate change and other impacts of human development, such as agricultural activities and land clearing, invasive species, exploitation of natural resources, and biotic interactions ${ }^{2,9}$. Third, there has been a trend towards increased accessibility of climate change data and predictions at finer spatiotemporal resolutions, making it more feasible to do biodiversity climate research $^{10,11}$.

What are the major directions being taken by the field of climate change and biodiversity research in recent years? Are there particular focal topics, or methods, that have drawn most attention? Here we summarise major trends in the recent highly cited literature of this field.

\section{Filtering and categorising the publications}

To select papers, we used the Web of Science indexing service maintained by Thomson Reuters, using the term "biodiversity AND (climate change)" to search within article titles, abstracts, and keywords. This revealed 3,691 matching papers spanning the 3-year period 2012 to 2014. Of these, 116 were categorised by

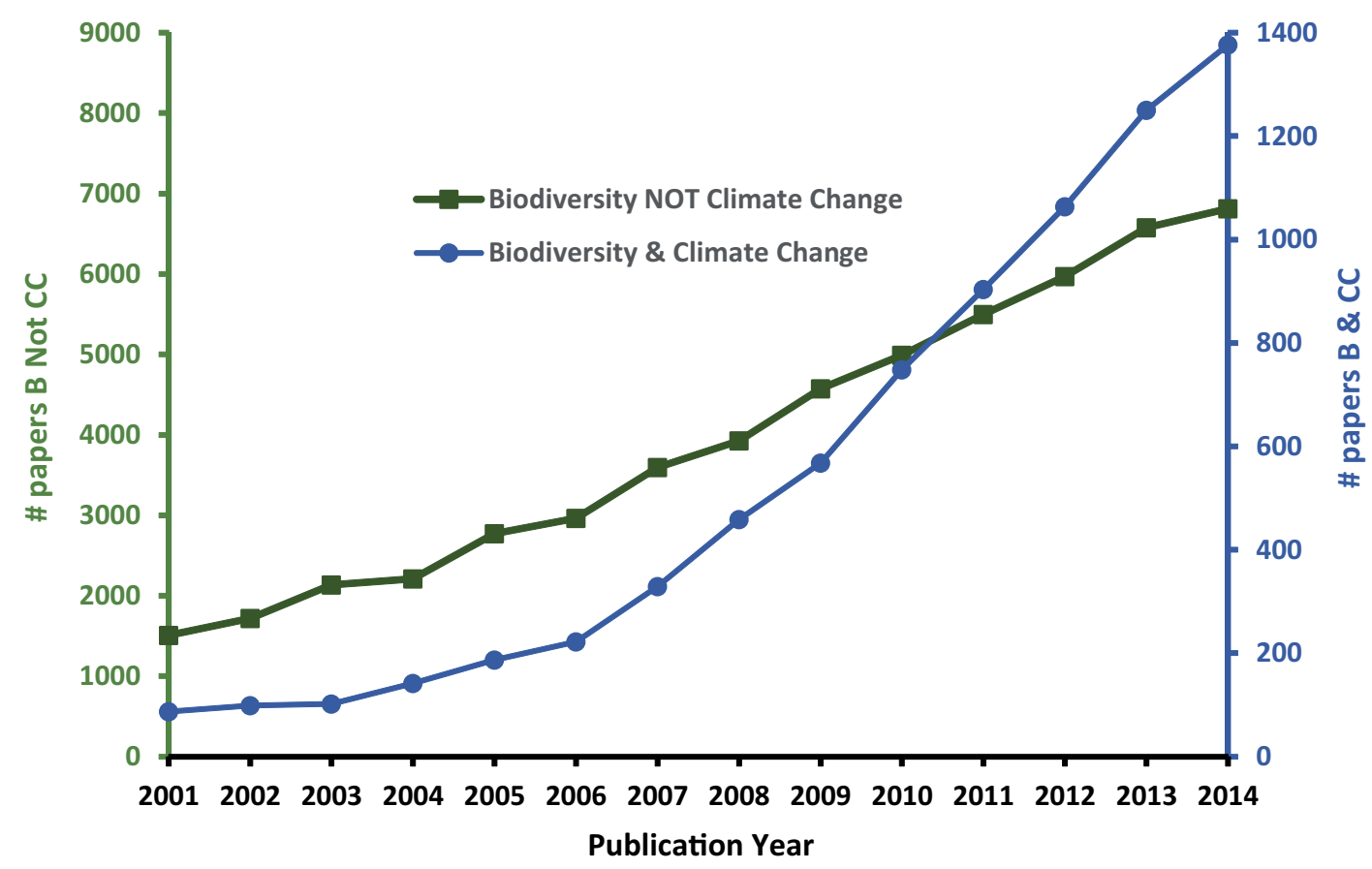

Figure 1. Relative growth of refereed studies on climate change and biodiversity, compared to non-climate-related biodiversity research. Number of refereed papers listed in the Web of Science database that were published between 2001 and 2014 on the specific topic "biodiversity AND (climate change)" (blue line, secondary y-axis) compared to the more general search term "biodiversity NOT (climate change)". 
Essential Science Indicators (esi.incites.thomsonreuters.com) as being "Highly Cited Papers" (definition: "As of November/December 2014 , this highly cited paper received enough citations to place it in the top $1 \%$ of [its] academic field based on a highly cited threshold for the field and publication year"), with five also being classed as "Hot Papers" (definition: "Published in the past two years and received enough citations in November/December 2014 to place it in the top $0.1 \%$ of papers in [its] academic field"). The two academic fields most commonly associated with these selected papers were "Plant \& Animal Science" and "Environment/Ecology".

Next we ranked each highly cited paper by year, according to its total accumulated citations through to April 1 2015, and then selected the top ten papers from each year (2012, 2013 and 2014) for detailed assessment. We wished to focus on data-oriented research papers, so only those labelled "Article" (Document Type) were considered, with "Review", "Editorial", or other non-research papers being excluded from our final list. Systematic reviews that included a formal meta-analysis were, however, included. We then further vetted each potential paper based on a detailed examination of its content, and rejected those articles for which the topics of biodiversity or climate change constituted only a minor component, or where these were only mentioned in passing (despite appearing in the abstract or key words).

The final list of 30 qualifying highly cited papers is shown in Table 1, ordered by year and first author. The full bibliographic details are given, along with a short description of the key message of the research (a subjective summary, based on our interpretation of the paper). Each paper was categorised by methodological type, the aspect of climate change that was the principal focus, the spatial and biodiversity scale of the study units, the realm, biome and taxa under study, the main ecological focus, and the research type and application (the first row of Table 1 lists possible choices that might be allocated within a given categorisation). Note that our choice of categories for the selected papers was unavoidably idiosyncratic, in this case being dictated largely by the most common topics that appeared in the reviewed papers. Other emphases, such as non-temperaturerelated drivers of global change, evolutionary responses, and so on, might have been more suitable for other bodies of literature. We also did not attempt to undertake any rigorous quantification of effect sizes in reported responses of biodiversity to climate change; such an approach would have required a systematic review and meta-analysis, which was beyond the scope of this overview of highly cited papers.

\section{Analysis of trends, biases and gaps}

Based on the categorisation frequencies in Table 1 (counts are given in the $n$ columns adjacent to each category), the "archetypal" highly cited paper in biodiversity and climate change research relies on a database of previously collated information, makes an assessment based on future forecasts of shifts in geographical distributions, is regional in scope, emphasises applied-management outcomes, and uses terrestrial plant species in temperate zones as the study unit.

Many papers also introduced new methodological developments, studied montane communities, took a theoretical-fundamental perspective, and considered physiological, population dynamics, and migration-dispersal aspects of ecological change. Plants were by far the dominant taxonomic group under investigation. By contrast, relatively few of the highly cited paper studies used experimental manipulations or network analysis; lake, river, island and marine systems were rarely treated; nor did they focus on behavioural or biotic interactions. Crucially, none of the highly cited papers relied on paleoclimate reconstructions or genetic information, despite the potential value of such data for model validation and contextualisation ${ }^{12}$. Such data are crucial in providing evidence for species responses to past environmental changes, specifying possible limits of adaptation (rate and extent) and fundamental niches, and testing theories of biogeography and macroecology.

At the time of writing, 5 of the 30 highly cited papers listed in Table 1 (16\%) also received article recommendations from Faculty of 1000 experts (f1000.com/prime/recommendations) ${ }^{9,13-16}$ with none of the most recent (2014) highly cited papers having yet received an F1000 Prime endorsement.

\section{Key findings of the highly cited paper collection for 2012-2014}

A broad conclusion of the highly cited papers for 2012-2014 (drawn from the "main message" summaries described in Table 1) is that the pace of climate change-forced habitat change, coupled with the increased frequency of extreme events ${ }^{15,17}$ and synergisms that arise with other threat drivers ${ }^{9,18}$ and physical barriers ${ }^{19}$, is typically outpacing or constraining the capacity of species, communities, and ecosystems to respond and adapt ${ }^{20,21}$. The combination of these factors leads to accumulated physiological stresses ${ }^{13,15,22}$, might have already induced an "extinction debt" in many apparently viable resident populations ${ }^{14,23-25}$, and is leading to changing community compositions as thermophilic species displace their more climate-sensitive competitors ${ }^{13,26}$. In addition to atmospheric problems caused by anthropogenic greenhouse-gas emissions, there is mounting interest in the resilience of marine organisms to ocean acidification $^{27,28}$ and altered nutrient flows ${ }^{16}$.

Although models used to underpin the forecasts of climate-driven changes to biotic populations and communities have seen major advances in recent years, as a whole the field still draws from a limited suite of methods, such as ecological niche models, matrix population projections and simple measures of change in metrics of ecological diversity ${ }^{7,22,29}$. However, new work is pushing the field in innovative directions, including a focus on advancements in dynamic habitat-vegetation models ${ }^{30-32}$, improved frameworks for projecting shifts in species distributions ${ }^{29,33,34}$ and how this might be influenced by competition or predation ${ }^{35,36}$, and analyses that seek to identify ecological traits that can better predict the relative vulnerability of different taxa to climate change ${ }^{37,38}$.

In terms of application of the research to conservation and policy, some offer local or region-specific advice on ecosystem management and its integration with other human activities (e.g., agriculture, fisheries) under a changing climate ${ }^{18,24,35,39}$. However, the majority of the highly cited papers used some form of forecasting to predict the consequences of different climate-mitigation scenarios (or business-as-usual) on biodiversity responses and extinctions $\mathrm{s}^{20-22,33,40}$, so as to illustrate the potentially dire consequences of inaction. 


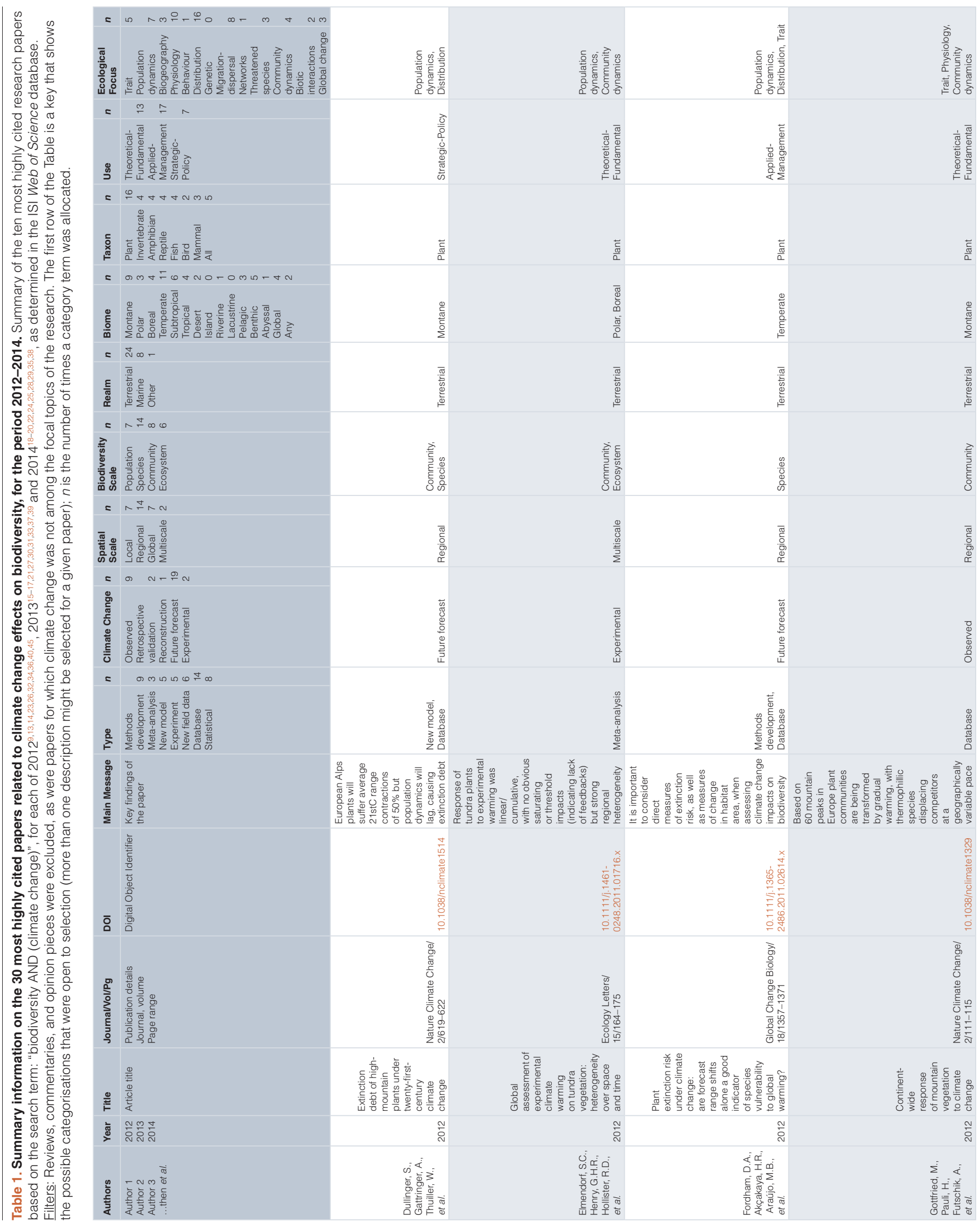




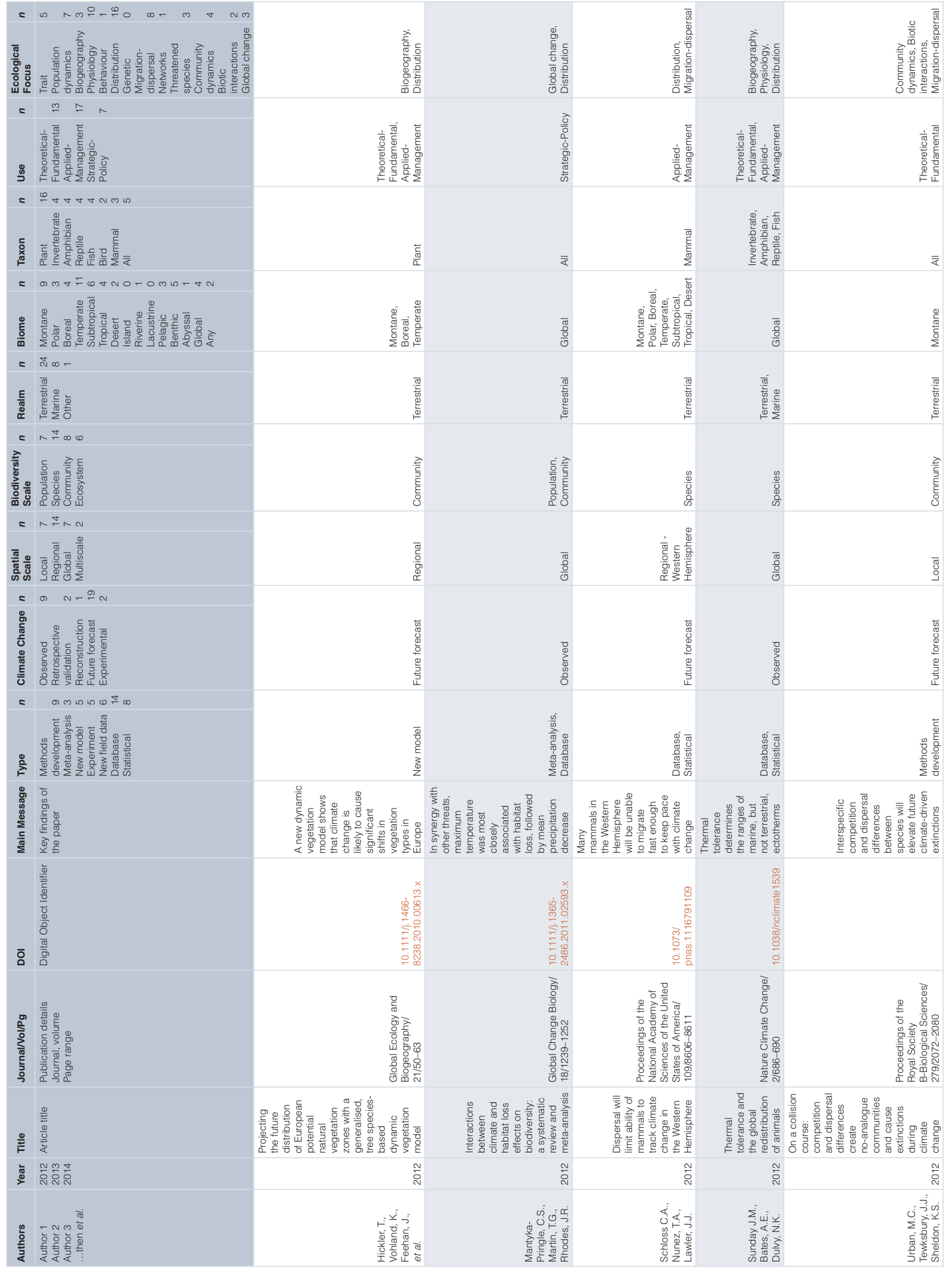




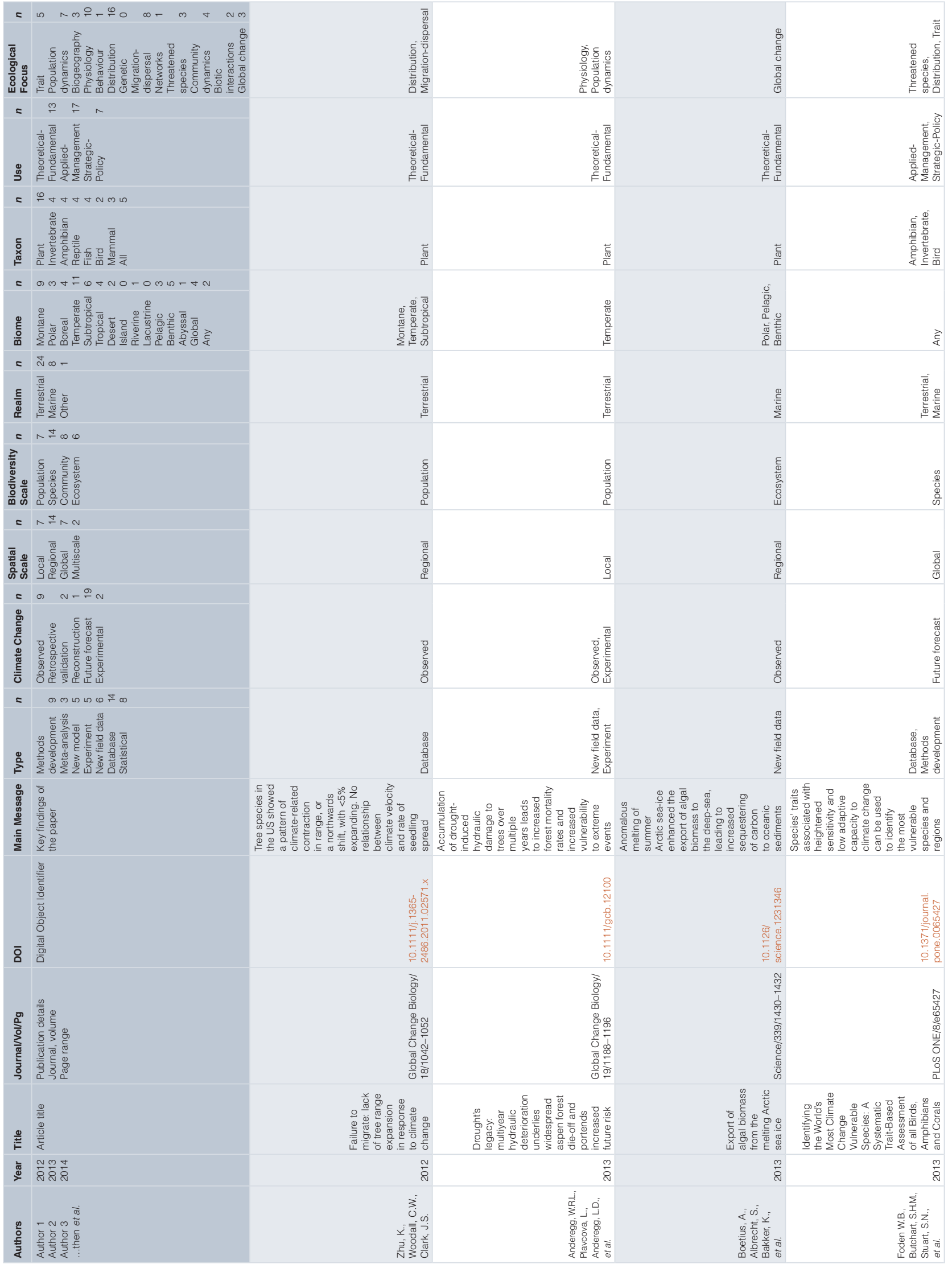




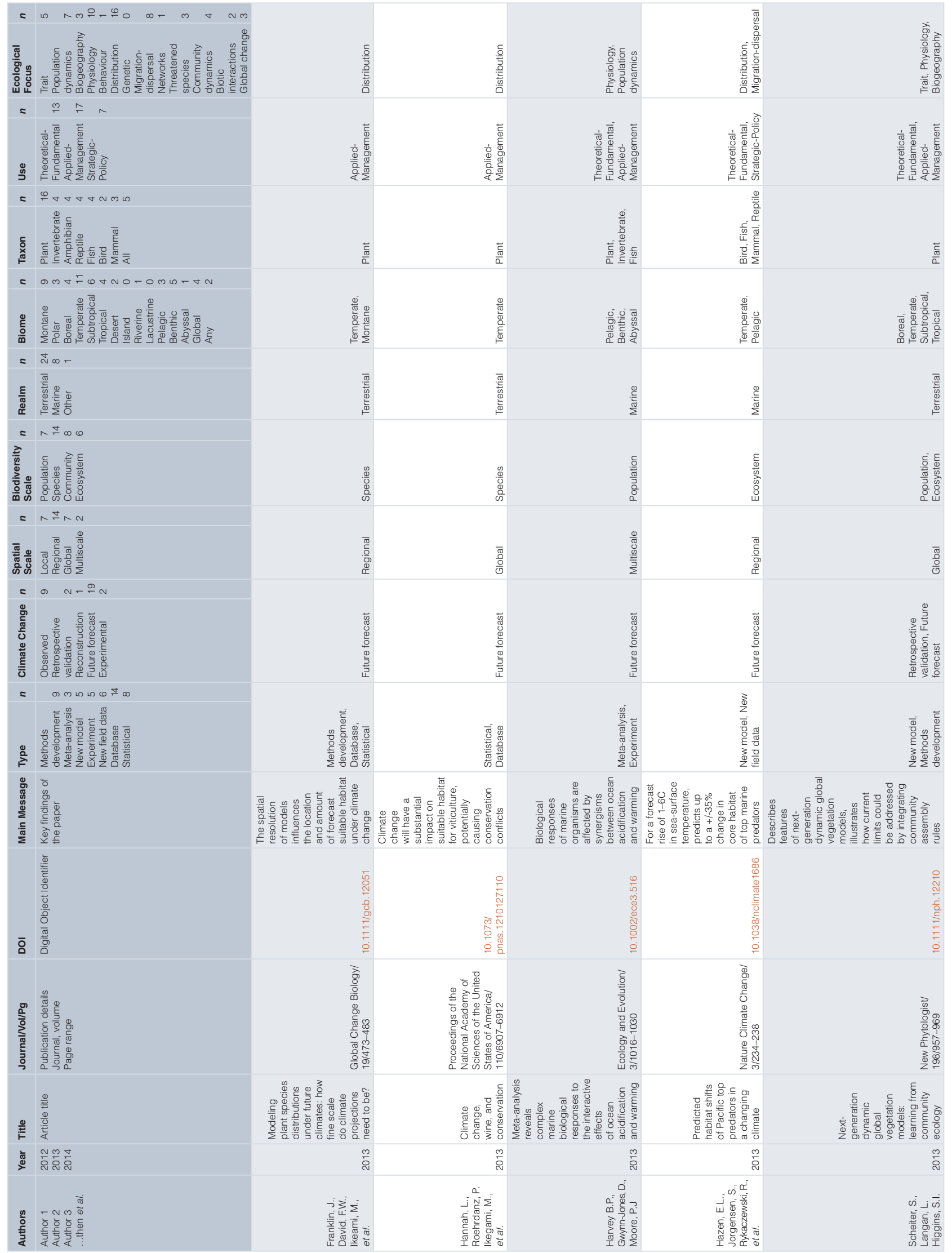




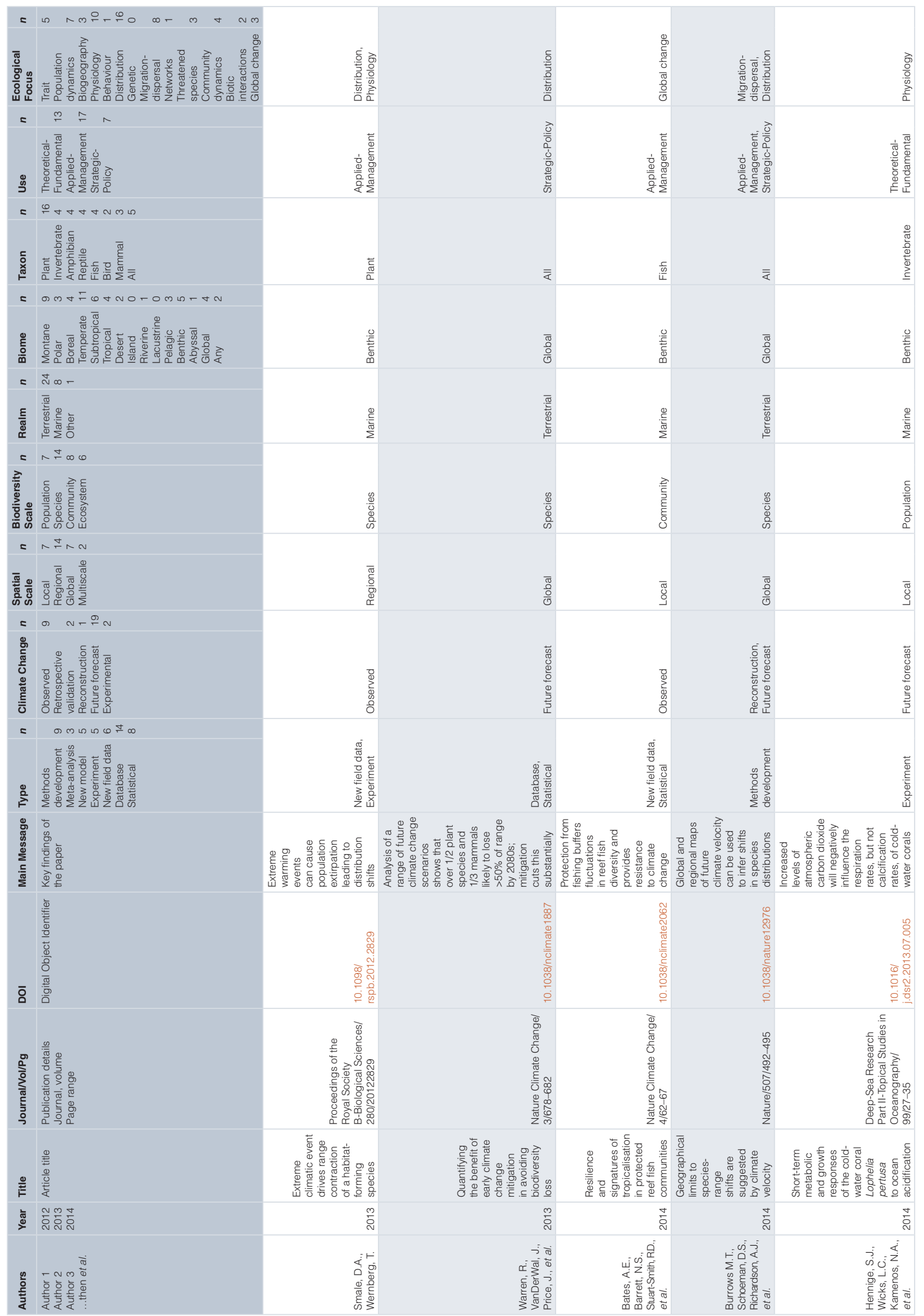




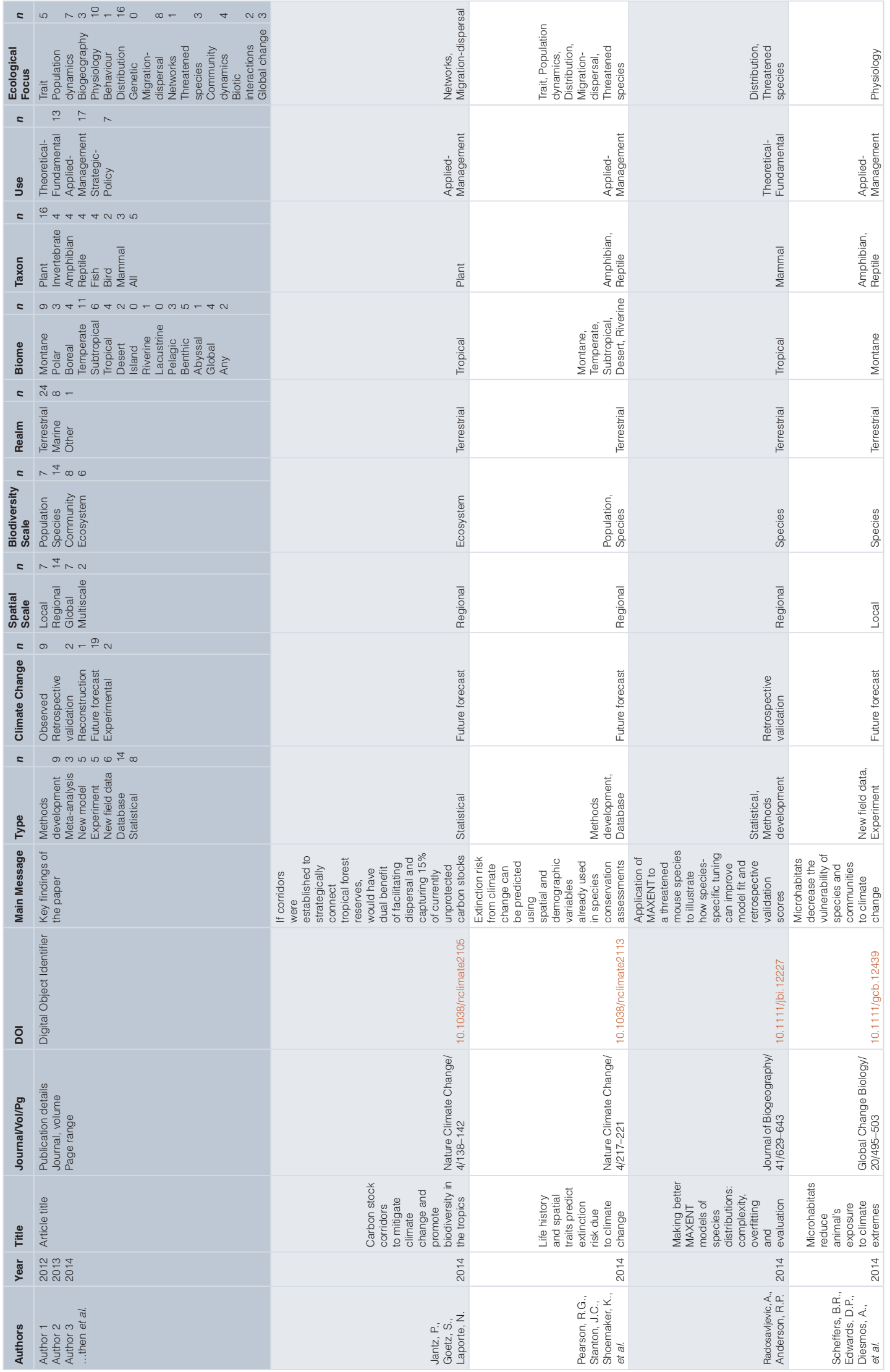




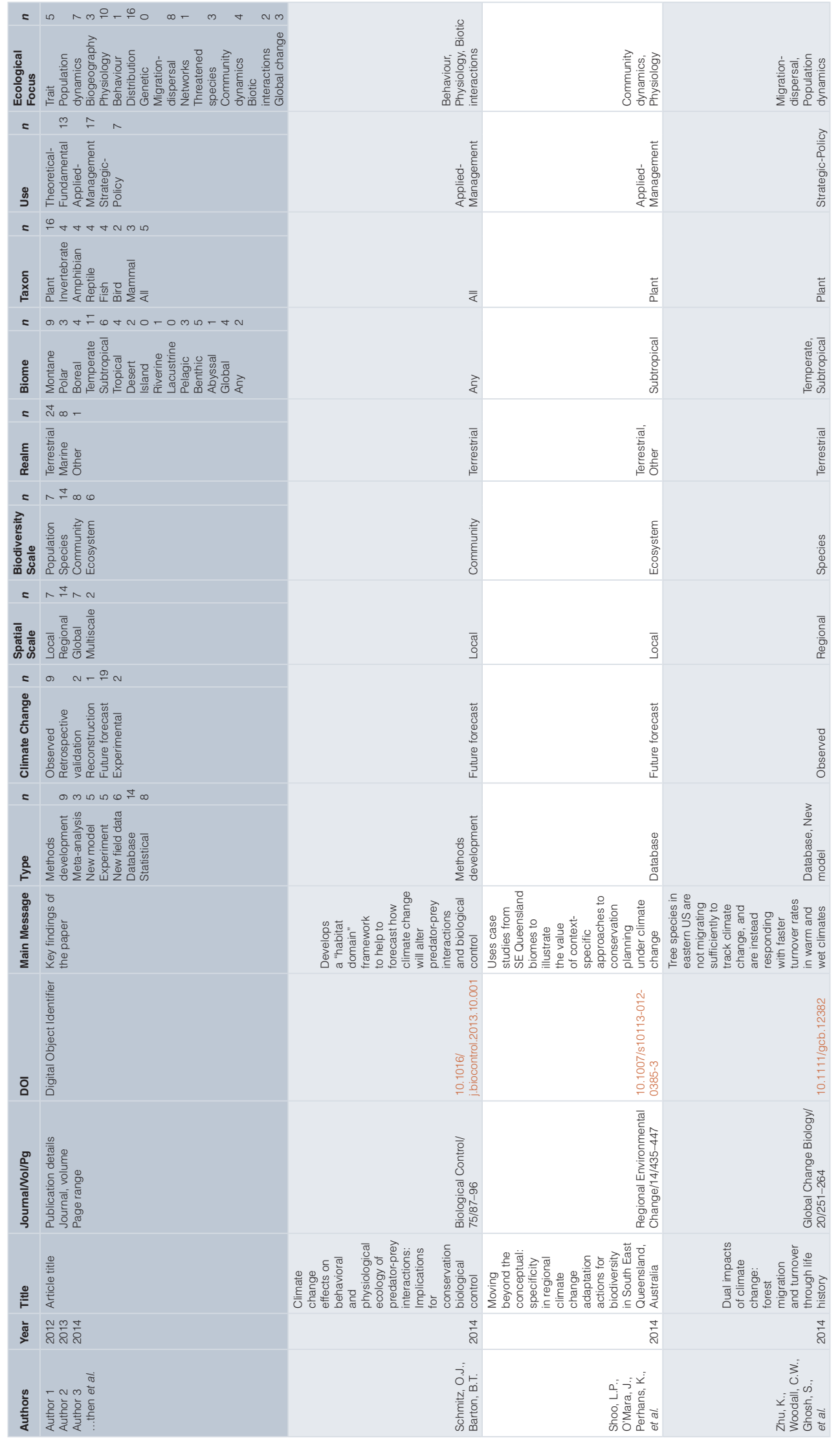




\section{Future directions}

The current emphasis on leveraging large databases for evidence of species responses to observed (recent) climate change is likely to wane as existing datasets are scrutinised repeatedly. This suggests to us that future research will be forced to move increasingly towards the logistically more challenging experimental manipulations (laboratory, mesocosm, and field-based). The likelihood of this shift in emphasis is reinforced by the recent trend towards mechanistic models in preference to correlative approaches ${ }^{41}$. Such approaches arguably offer the greatest potential to yield highly novel insights, especially for predicting and managing the outcomes of future climate-ecosystem interactions that have no contemporary or historical analogue. Along with this work would come an increasing need for systematic reviews and associated meta-analysis, to summarise these individual studies quantitatively and use the body of experiments to test hypotheses.

Technological advances will also drive this field forward. This includes the development of open-source software and function libraries that facilitate and standardise routine tasks like validation and sensitivity analysis of projection or statistical models ${ }^{42,43}$, as well as improved access to data layers from large spatio-temporal datasets like ensemble climate forecasts ${ }^{10}$ and palaeoclimatic hindcasts ${ }^{44}$. An increasing emphasis on cloud-based storage and use of off-site high-performance parallel computing infrastructure will make it realistic for researchers to undertake computationally intensive tasks ${ }^{31}$ from their desktop.
These approaches are beginning to emerge, and a few papers on these topics already appear in the highly cited paper list (Table 1). This includes the innovative exposure of coral populations to varying carbon dioxide concentrations, and the meta-analyses of tundra plant response to experimental warming ${ }^{45}$ and marine organisms to ocean chemistry ${ }^{27}$. Such work must also be underpinned by improved models of the underlying mechanisms and dynamic processes, ideally using multi-species frameworks that make use of ensemble forecasting methods for improved incorporation of scenario and climate model uncertainty ${ }^{10}$. Such an approach can account better for biotic interactions ${ }^{41}$ via individual-based and physiologically explicit "bottom-up" models of adaptive responses ${ }^{31}$. Lastly, there must be a greater emphasis on using genetic information to integrate eco-evolutionary processes into biodiversity models ${ }^{46}$, and on improving methods for making the best use of retrospective knowledge from palaeoecological data ${ }^{12}$.

\section{Competing interests}

The authors declare that they have no disclosures or conflicts of interest.

\section{Grant information}

This work was supported by Australian Research Council Discovery Grant DP120101019 (Brook) and Future Fellowship FT140101192

(Fordham).
1. Diamond JM: "Normal" extinctions of isolated populations. In Extinctions, MH Nitecki (Ed.), Chicago University Press, 1984; 191-246. Reference Source

2. Brook BW, Sodhi NS, Bradshaw CJ: Synergies among extinction drivers under global change. Trends Ecol Evol. 2008; 23(8): 453-460 PubMed Abstract | Publisher Full Text

3. IPCC. Intergovernmental Panel on Climate Change: Fourth (AR4) and Fifth (AR5) Assessment Reports: Working Group II Report on Impacts, Adaptation, and Vulnerability. 2001, 2007 Reference Source

4. MEA. Millennium Ecosystem Assessment: Ecosystems and Human Well-being: Scenarios. Island Press, 2005. Reference Source

5. F Urban MC: Accelerating extinction risk from climate change. Science. 2015; 348(6234): 571-573.

Publisher Full Text | F1000 Recommendation

6. Brook BW, Rowley N, Flannery TF: Kyoto: doing our best is no longer enough. Nature. 2007; 450(7169): 478-478. PubMed Abstract | Publisher Full Text

7. F Dawson TP, Jackson ST, House JI, et al:: Beyond predictions: biodiversity conservation in a changing climate. Science. 2011; 332(6025): 53-58. PubMed Abstract | Publisher Full Text | F1000 Recommendation

8. F Pereira HM, Navarro LM, Martins IS: Global biodiversity change: The bad the good, and the unknown. Annu Rev Environ Resour. 2012; 37: 25-50. Publisher Full Text | F1000 Recommendation

9. Mantyka-Pringle CS, Martin TG, Rhodes JR: Interactions between climate and habitat loss effects on biodiversity: a systematic review and meta-analysis. Glob Chang Biol. 2012; 18(4): 1239-1252.

Publisher Full Text
10. Fordham DA, Wigley TML, Brook BW: Strengthening forecasts of climate change impacts with multi-model ensemble averaged projections using MAGICC/SCENGEN 5.3. Ecography. 2012; 35(1): 4-8. Publisher Full Text

11. F Hijmans RJ, Cameron SE, Parra JL, et al.: Very high resolution interpolated climate surfaces for global land areas. Int J Climatol. 2005; 25(15): 1965-1978.

Publisher Full Text | F1000 Recommendation

12. Fordham DA, Brook BW, Moritz $C$, et al.: Better forecasts of range dynamics using genetic data. Trends Ecol Evol. 2014; 29(8): 436-443. PubMed Abstract | Publisher Full Text

13. Sunday JM, Bates AE, Dulvy NK: Thermal tolerance and the global redistribution of animals. Nat Clim Chang. 2012; 2: 686-690. Publisher Full Text

14. Zhu K, Woodall $\mathrm{CW}$, Clark JS: Failure to migrate: lack of tree range expansion in response to climate change. Glob Chang Biol. 2012; 18(3): 1042-1052. Publisher Full Text

15. F Anderegg WR, Plavcova L, Anderegg LD, et al.: Drought's legacy: multiyear hydraulic deterioration underlies widespread aspen forest die-off and portends increased future risk. Glob Chang Biol. 2013; 19(4): 1188-1196. PubMed Abstract | Publisher Full Text | F1000 Recommendation

16. F Boetius A, Albrecht S, Bakker K, et al:: Export of algal biomass from the melting arctic sea ice. Science. 2013; 339(6126): 1430-1432. PubMed Abstract | Publisher Full Text | F1000 Recommendation

17. Smale DA, Wernberg $\mathrm{T}$ : Extreme climatic event drives range contraction of a habitat-forming species. Proc Biol Sci. 2013; 280(1754): 20122829. PubMed Abstract | Publisher Full Text | Free Full Text

18. F Bates AE, Barrett NS, Stuart-Smith RD, et al:: Resilience and signatures of ropicalisation in protected reef fish communities. Nat Clim Chang. 2014; 4(1): 
$62-67$.

Publisher Full Text | F1000 Recommendation

19. Jantz P, Goetz S, Laporte N: Carbon stock corridors to mitigate climate change and promote biodiversity in the tropics. Nat Clim Chang. 2014; 4: 138-142. Publisher Full Text

20. F Burrows MT, Schoeman DS, Richardson AJ, et al:: Geographical limits to species-range shifts are suggested by climate velocity. Nature. 2014; 507(7493): 492-495.

PubMed Abstract | Publisher Full Text | F1000 Recommendation

21. F Warren R, VanDerWal J, Price J, et al.: Quantifying the benefit of early climate change mitigation in avoiding biodiversity loss. Nat Clim Chang. 2013; 3(7): 678-682.

Publisher Full Text | F1000 Recommendation

22. Scheffers BR, Edwards DP, Diesmos A, et al:: Microhabitats reduce animal's exposure to climate extremes. Glob Chang Biol. 2014; 20(2): 495-503. PubMed Abstract | Publisher Full Text

23. Dullinger S, Gattringer A, Thuiller W, et al.: Extinction debt of high-mountain plants under twenty-first-century climate change. Nat Clim Chang. 2012; 2 : 619-622.

Publisher Full Text

24. Shoo LP, O'Mara J, Perhans K, et al:: Moving beyond the conceptual: specificity in regional climate change adaptation actions for biodiversity in South East Queensland, Australia. Reg Environ Change. 2014; 14(2): 435-447. Publisher Full Text

25. Zhu K, Woodall CW, Ghosh S, et al:: Dual impacts of climate change: forest migration and turnover through life history. Glob Chang Biol. 2014; 20(1): 251-64.

PubMed Abstract | Publisher Full Text

26. F Gottfried M, Pauli H, Futschik A, et al:: Continent-wide response of mountain vegetation to climate change. Nat Clim Chang. 2012; 2(2): 111-115. Publisher Full Text | F1000 Recommendation

27. F Harvey BP, Gwynn-Jones D, Moore PJ: Meta-analysis reveals complex marine biological responses to the interactive effects of ocean acidification and warming. Ecol Evol. 2013; 3(4): 1016-1030.

PubMed Abstract | Publisher Full Text | Free Full Text | F1000 Recommendation

28. F Hennige SJ, Wicks LC, Kamenos NA, et al:: Short-term metabolic and growth responses of the cold-water coral Lophelia pertusa to ocean acidification. Deep Sea Res Part II To Stud Oceanogr. 2014; 99: 27-35. Publisher Full Text | F1000 Recommendation

29. F Radosavljevic A, Anderson RP: Making better MAXENT models of species distributions: complexity, overfitting and evaluation. J Biogeogr. 2014; 41(4): 629-643.

Publisher Full Text | F1000 Recommendation

30. Franklin J, Davis FW, lkegami M, et al.: Modeling plant species distributions under future climates: how fine scale do climate projections need to be? Glob Chang Biol. 2013; 19(2): 473-483. PubMed Abstract | Publisher Full Tex

31. F Scheiter S, Langan L, Higgins SI: Next-generation dynamic global vegetation models: learning from community ecology. New Phytol. 2013; 198(3): 957-969.

PubMed Abstract | Publisher Full Text | F1000 Recommendation

32. F Hickler T, Vohland K, Feehan J, et al:: Projecting the future distribution of European potential natural vegetation zones with a generalised, tree species-based dynamic vegetation model. Global Ecol Biogeogr. 2012; 21(1):
$50-63$

Publisher Full Text | F1000 Recommendation

33. F Hazen EL, Jorgensen S, Rykaczewski RR, et al:: Predicted habitat shifts of Pacific top predators in a changing climate. Nat Clim Chang. 2013; 3(3): 234-238.

Publisher Full Text | F1000 Recommendation

34. Fordham DA, Akçakaya HR, Araujo MB, et al:: Plant extinction risk under climate change: are forecast range shifts alone a good indicator of species vulnerability to global warming? Glob Chang Biol. 2012; 18(4): 1357-1371. Publisher Full Text

35. Schmitz OJ, Barton BT: Climate change effects on behavioral and physiological ecology of predator-prey interactions: Implications for conservation biological control. Biol Control. 2014; 75: 87-96. Publisher Full Text

36. F Urban MC, Tewksbury JJ, Sheldon KS: On a collision course: competition and dispersal differences create no-analogue communities and cause extinctions during climate change. Proc Biol Sci. 2012; 279(1735): 2072-2080. PubMed Abstract | Publisher Full Text | Free Full Text | F1000 Recommendation

37. F Foden WB, Butchart SH, Stuart SN, et al:: Identifying the world's most climate change vulnerable species: a systematic trait-based assessment of all birds, amphibians and corals. PLOS One. 2013; 8(6): e65427.

PubMed Abstract | Publisher Full Text | Free Full Text | F1000 Recommendation

38. Pearson RG, Stanton JC, Shoemaker KT, et al.: Life history and spatial traits predict extinction risk due to climate change. Nat Clim Chang. 2014; 4: 217-221. Publisher Full Text

39. Hannah L, Roehrdanz PR, Ikegami M, et al.: Climate change, wine, and conservation. Proc Natl Acad Sci U S A. 2013; 110(17): 6907-6912. PubMed Abstract | Publisher Full Text | Free Full Text

40. Schloss CA, Nuñez TA, Lawler JJ: Dispersal will limit ability of mammals to track climate change in the Western Hemisphere. Proc Natl Acad Sci U S A. 2012; 109(22): 8606-8611.

PubMed Abstract | Publisher Full Text | Free Full Text

41. Fordham DA, Akçakaya HR, Brook BW, et al:: Adapted conservation measures are required to save the Iberian lynx in a changing climate. Nat Clim Chang. 2013; 3: 899-903.

Publisher Full Text

42. Watts MJ, Fordham DA, Akçakaya HR, et al:: Tracking shifting range margins using geographical centroids of metapopulations weighted by population density. Ecol Modell. 2013; 269: 61-69. Publisher Full Text

43. Lurgi M, Brook BW, Saltré $\mathrm{F}$, et al:: Modelling range dynamics under global change: which framework and why? Methods Ecol Evol. 2015; 6(3): 247-256. Publisher Full Text

44. Liu Z, Otto-Bliesner BL, He F, et al.: Transient simulation of last deglaciation with new mechanism for Bolling-Allerod warming. Science. 2009; 325(5938): 310-314. PubMed Abstract | Publisher Full Text

45. F Elmendorf SC, Henry GH, Hollister RD, et al.: Global assessment of experimental climate warming on tundra vegetation: heterogeneity over space and time. Ecol Lett. 2012; 15(2): 164-175. PubMed Abstract | Publisher Full Text | F1000 Recommendation

46. $\quad \mathrm{F}$ Thuiller W, Münkemüller $\mathrm{T}$, Lavergne $\mathrm{S}$, et al.: A road map for integrating eco-evolutionary processes into biodiversity models. Ecol Lett. 2013; 16(Suppl 1): 94-105.

PubMed Abstract | Publisher Full Text | Free Full Text | F1000 Recommendation 


\section{Open Peer Review}

\section{Current Peer Review Status:}

\section{Version 1}

Reviewer Report 01 October 2015

https://doi.org/10.5256/f1000research.6984.r10635

(C) 2015 Schmid B. This is an open access peer review report distributed under the terms of the Creative Commons Attribution License, which permits unrestricted use, distribution, and reproduction in any medium, provided the original work is properly cited.

\section{Bernhard Schmid}

Institute of Evolutionary Biology and Environmental Studies, University of Zurich, Zurich, CH-8057, Switzerland

Competing Interests: No competing interests were disclosed.

I confirm that I have read this submission and believe that I have an appropriate level of expertise to confirm that it is of an acceptable scientific standard.

Reviewer Report 01 October 2015

https://doi.org/10.5256/f1000research.6984.r10634

(c) 2015 Rhodes J. This is an open access peer review report distributed under the terms of the Creative Commons Attribution License, which permits unrestricted use, distribution, and reproduction in any medium, provided the original work is properly cited.

\section{Jonathan Rhodes}

Landscape Ecology and Conversation Group, University of Queensland, Brisbane, QId, Australia

Competing Interests: No competing interests were disclosed.

I confirm that I have read this submission and believe that I have an appropriate level of expertise to confirm that it is of an acceptable scientific standard. 


\section{Comments on this article}

\section{Version 1}

Reader Comment 29 Oct 2015

Petr Keil, iDiv, Germany

Oh, I am sorry, the papers that include climate change indeed did grow faster -- I made a mistake in my previous comment. But I maintain that Figure 1 is a confusing way to show that (it confused me). Perhaps the best way would be to present two figures: one with absolute numbers of papers on y-axis, another one with proportions on y-axis.

Competing Interests: No competing interests were disclosed.

\section{Reader Comment 29 Oct 2015}

Petr Keil, iDiv, Germany

I think that the $y$-axes in Figure 1 should be changed, so that there is only one axis for both of the curves -- the curves should use the same units. Otherwise the paper makes a false impression that biodiversity and climate change papers grew faster than papers that do not deal with climate change.

Competing Interests: No competing interests were disclosed.

The benefits of publishing with F1000Research:

- Your article is published within days, with no editorial bias

- You can publish traditional articles, null/negative results, case reports, data notes and more

- The peer review process is transparent and collaborative

- Your article is indexed in PubMed after passing peer review

- Dedicated customer support at every stage

For pre-submission enquiries, contact research@f1000.com 